\title{
THE SOUTHERNMOST BEAR: PARARCTOTHERIUM (CARNIVORA, URSIDAE, TREMARCTINAE) IN THE LATEST PLEISTOCENE OF SOUTHERN PATAGONIA, CHILE
}

FRANCISCO J. PREVOSTI ${ }^{1}$, LEOPOLDO H. SOIBELZON ${ }^{2}$, ALFREDO PRIETO ${ }^{3}$, MANUEL SAN ROMAN ${ }^{4}$, and FLAVIA MORELLO ${ }^{3}$, ${ }^{1}$ Facultad de Ciencias Naturales y Museo (U.N.L.P.), cc 223, 1900 La Plata, Buenos Aires, Argentina, protocyon@ $@$ hotmail.com; ${ }^{2}$ CONICET, Departamento Científico Paleontología de Vertebrados, Museo de La Plata, Paseo del Bosque, 1900 La Plata, Buenos Aires, Argentina; ${ }^{3}$ Centro de Estudios del Hombre Austral, Instituto de la Patagonia, UMAG Casilla 113-D, Punta Arenas, Chile; ${ }^{4}$ Centro de Estudios del Cuaternario de Fuego-Patagonia y Antártica Chilena, Casilla 113-D, Punta Arenas, Chile

A second upper incisor belonging to the tremarctine bear Pararctotherium was recovered from latest Pleistocene deposits in Cueva de los Chingues, Magallanes, Chile (San Roman et al., 2000; Fig. 1). This is the southernmost record of an ursid in the world and one of the youngest records of Pararctotherium. The paleoenvironment of southern Patagonia in the latest Pleistocene (ca. 11,000 yBP) was a cold grassland.

The Ursidae originated during the late Eocene in the Holarctic region and throughout its history has primarily been restricted to the Northern Hemisphere. Ursids twice dispersed into Africa (Hunt, 1996): the Hemicyoninae in the early Miocene and Agriotherium in the late Miocene, with the latter reaching the southern tip of Africa (ca. $33^{\circ} 43^{\prime} \mathrm{S}$ ). The Tremarctinae is comprised of five genera: Plionarctos, late Mioceneearly Pliocene, North America (Tedford and Martin, 2001); Arctodus, late Pliocene-Pleistocene, North America (Kurtén, 1967; Emslie, 1995); Arctotherium and Pararctotherium, Pleistocene, South America; and Tremarctos, late Pliocene-Pleistocene, North America and Recent, South America (Kurtén, 1966). Trajano and Ferrarezzi (1994) considered Pararctotherium to be a subgenus of Arctotherium. We regard both Arctotherium and Pararctotherium as valid, distinct genera based on the systematic and phylogenetic revision of South American fossil bears by LHS (e.g., Soibelzon, 2000, 2002; Soibelzon et al., 2000).

Tremarctines dispersed into South America from North America at least twice. The oldest records of Arctotherium are early Pleistocene (Ensenadan age; Kraglievich and Ameghino, 1940; Berman, 1994; Soibelzon and Bond, 1998; Soibelzon et al., 2001; Soibelzon, 2002). Tremarctos, which lacks a fossil record in South America, probably crossed the Panamanian Isthmus in the latest Pleistocene or Holocene (Soibelzon, 2002). South American fossil bears are primarily recovered from the Pampean Region (ca. 33 ${ }^{\circ} \mathrm{S}$ ), with isolated finds in Brazil, Bolivia, Chile, Venezuela, and Uruguay. Arctotherium latidens is the lone Ensenadan tremarctine in South America. Following its extinction, tremarctines were represented by several species of Pararctotherium during the middle to late Pleistocene (Bonaerian and Lujanian ages; Cione and Tonni, 1999). It was distributed widely across southern South America (Bolivia, Brazil, Argentina, Uruguay, and Chile) and persisted until the end of the Lujanian (Soibelzon and Bond, 1998; Soibelzon, 2002).

Abbreviations-MLP, Museo de La Plata, Argentina; MMP, Museo Municipal de Mar del Plata "Lorenzo Scaglia", Argentina; MACN, Museo Argentino de Ciencias Naturales "Bernardino Rivadavia", Argentina; UMAG, Universidad de Magallanes, Chile; W, maximum transversal width; L, maximum anteroposterior length.

\section{SYSTEMATIC PALEONTOLOGY}

Class MAMMALIA Linnaeus, 1758

Order CARNIVORA Bowdich, 1821

Family URSIDAE Gray, 1825

Subfamily TREMARCTINAE Merriam and Stock, 1925

PARARCTOTHERIUM Ameghino, 1904 PARARCTOTHERIUM sp.

Referred Specimen-UMAG 53643 (Fig. 2A-C, Table 1), left I2. Locality and Age - Cueva de los Chingues, Pali Aike National Park,

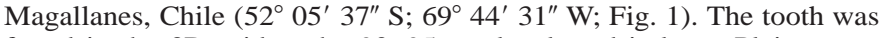
found in the $3 \mathrm{D}$ grid at the $90-95 \mathrm{~cm}$ level, and is latest Pleistocene. San Roman et al. (2000) reported that collagen taken from a bone of Hippidion sp. from this level had a date of $11,210 \pm 50{ }^{14} \mathrm{C}$ yBP (=13,410-13,010 cal. yBP).

Description-The crown is proportionally high, and laterally narrow, especially in its middle and lower portions. In occlusal view (Fig. 2B), it is subtriangular in outline, more elongated anteroposteriorly, with the apex oriented lingually. The principal cusp is anteroposteriorly compressed and laterally expanded, with a small cuspule on the lateral side. The enamel of the anterior face is wrinkled and has a shallow longitudinal groove. The medial border is slightly convex (mainly at the base of the crown), but the lateral border is concave. The lingual shelf is subhorizontal, slightly inclined lingually, with two rounded ridges at the medial and lateral border. The lateral ridge is shorter and narrower than the medial ridge. A very small enamel bulge is located between these ridges and the principal cusp.

Comparisons-UMAG 53643 displays the morphology of a tremarctine I1 or I2. It is not shovel-shaped, as are the lower incisors, and has a triangular occlusal edge (Emslie, 1995). We identify UMAG 53643 as an I2 because in most tremarctines the I2 is larger than I1, more triangular in occlusal view, and has a longer inner shelf. The I3 is caniniform in all Ursidae.

Tremarctines are the only ursids known from South America, with two extinct genera, Arctotherium and Pararctotherium, and the extant Tremarctos ornatus from northwestern South America. The I2 of Pararctotherium is very different from that of Arctotherium (Fig. 2D-G). The I2 of Pararctotherium is smaller than that of Arctotherium (Table 1 ) and the lingual ridges are rounded and flat without cusps on their anterior boundary. Pararctotherium has a small enamel bulge absent in Arctotherium. The longitudinal groove between the two ridges is deeper in Arctotherium. In addition, Arctotherium has a well developed cusp on the lateral margin of the principal cusp, which is reduced or absent in Pararctotherium (Fig. 2D-G). Upper incisors of Tremarctos ornatus are much smaller than those of Arctotherium or Pararctotherium.

The I2 from Cueva de los Chingues has the same morphology and size as those of Pararctotherium (Table 1). It is nearly indistinguishable from MACN 971, the holotype of Pararctotherium pamparum (Fig. 2F, G) and very similar to Pararctotherium brasiliense (Paula Couto, 1960: fig. 4; Cartelle, 1994:90). Unfortunately, the third species of Pararctotherium, $P$. enectum, is know only from mandibles. Because of this and the rarity of incisors of Pararctotherium, we could not make a definitive specific determination.

The only other large carnivores in southern Patagonia during the latest Pleistocene were the lion-sized Patagonian panther (Panthera onca mesembryna) and Smilodon (Borrero, 1997). The I1 and I2 of the Patagonian panther are smaller than those of Pararctotherium, and their crowns are shorter and more expanded laterally. The lingual faces are less compressed and more squared in cross-section than those of Pararctotherium. The inner cingula run along the lingual border of the teeth, reaching their maximum height at the midline and are separated from the principal cusp by a transverse groove. The morphology of the upper incisors of Smilodon is significantly different: the principal cusp 


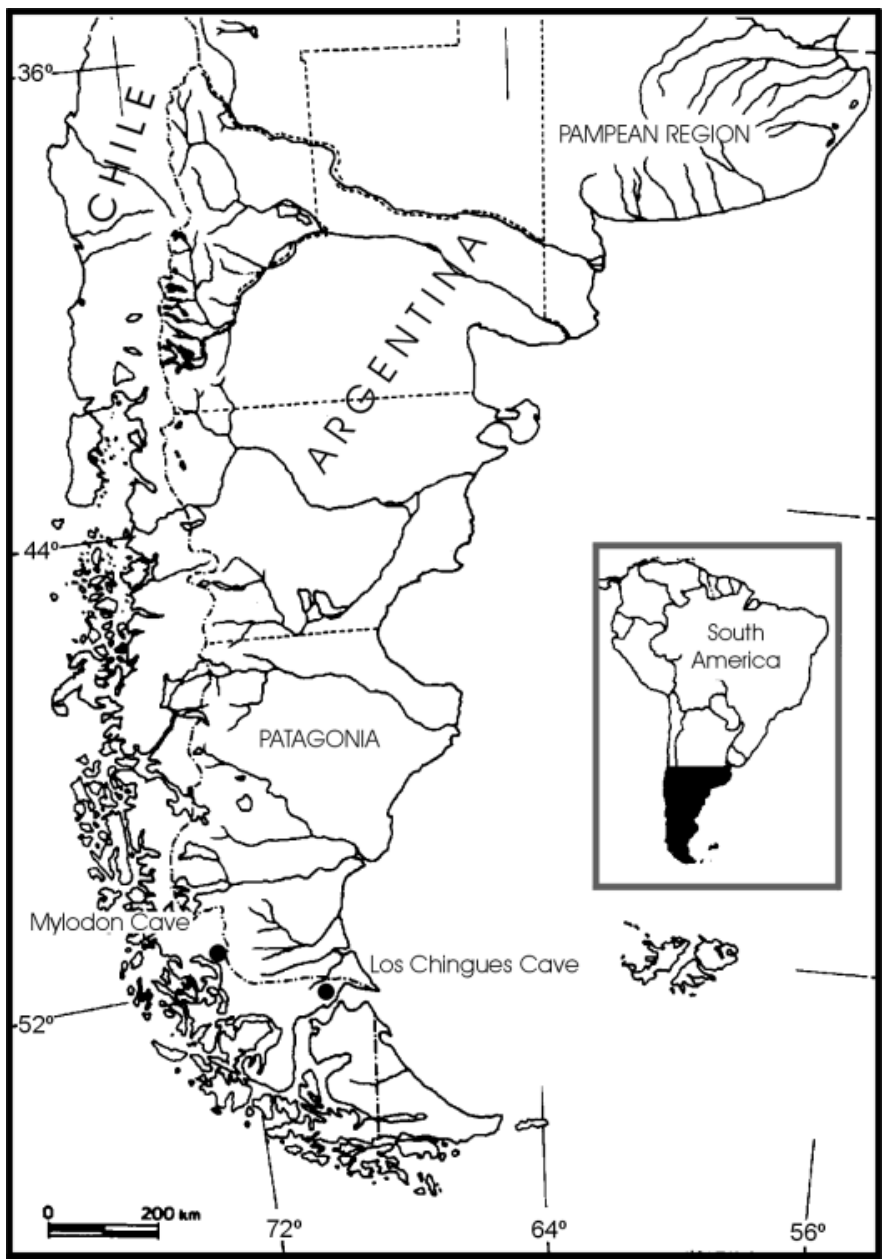

FIGURE 1. Map showing the position of Cueva de los Chingues and Cueva del Mylodon in southern Chile.

is large, conical in shape, recurved, and elliptical in occlusal view, with ridges at its medial and lateral faces (Merriam and Stock, 1932).

\section{PALEOBIOGEOGRAPHIC SIGNIFICANCE}

Pararctotherium is known from Brazil (P. brasiliense; Paula Couto, 1960; Trajano and Ferrarezzi, 1994), Uruguay (P. pamparum; Perea and Ubilla, 1983), and Argentina (P. enectum and P. pamparum; Ameghino, 1904; Berman, 1994; Soibelzon and Bond, 1998). The most southern record, outside Patagonia, is a mandible of $P$. pamparum from the late Pleistocene (Bonaerian or Lujanian age) of the southern Pampean Region $\left(38^{\circ} 38^{\prime} \mathrm{S} ; 60^{\circ} 36^{\prime} \mathrm{W}\right)$. The latest records of fossils tremarctinaes come from Young, Uruguay (ca. 11,600 \pm 130 yBP; Ubilla and Perea $1999)$ and Santa Clara del Mar, Argentina $\left(24,450 \pm 150{ }^{14} \mathrm{C}\right.$ yBP, at $37^{\circ} 49^{\prime} \mathrm{S} ; 57^{\circ} 29^{\prime} \mathrm{W}$; Pardiñas et al., 1998). Some records of $P$. bras iliense have been considered latest Pleistocene to Holocene (Paula Couto, 1960; Trajano and Ferrarezzi, 1994; Cartelle, 1998), but as the fossils were collected out of stratigraphic context, their age cannot be determined accurately.

In 1900, a portion of femur found in the Cueva del Mylodon (Ultima Esperanza, Chile; $52^{\circ} 05^{\prime} 37^{\prime \prime} \mathrm{S}$; $69^{\circ} 44^{\prime} 31^{\prime \prime} \mathrm{W}$; Fig. 1) was referred to Arctotherium sp. (Smith Woodward, 1900). Later, Oliver (1935) assigned it to Pararctotherium pamparum. Although the specimen is now lost, the size and morphology of are those of the femur of Pararctotherium, but it cannot be assigned to any particular species. Curiously, this record was ignored in revisions of South American fossil Tremarctinae (e.g., Kraglievich, 1926, 1934; Kraglievich and Ameghino, 1940 Kurtén, 1967; Berman, 1994; Trajano and Ferrarezi, 1994). The discovery of an I2 of Pararctotherium at Cueva de los Chingues confirms the presence of the genus during the latest Pleistocene of southern Pata-

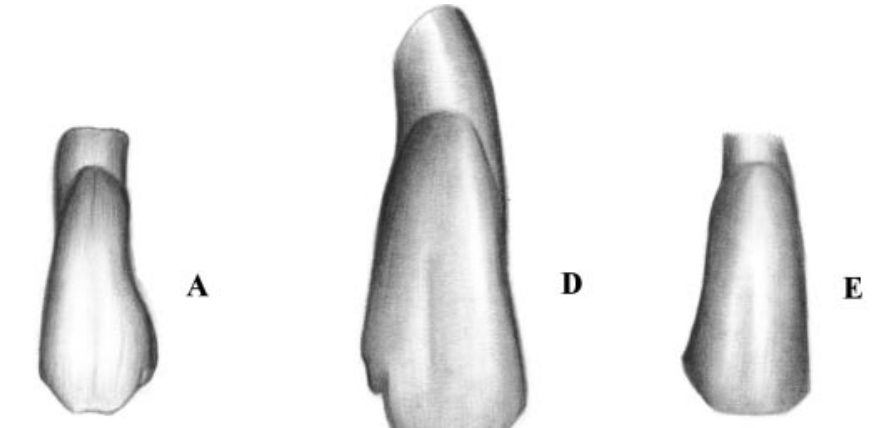

B

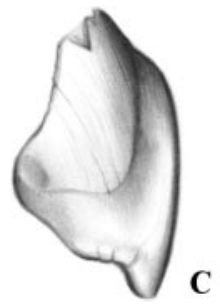

FIGURE 2. Comparison of I2 of Arctotherium and Pararctotherium. Labial (A), occlusal (B), and lateral (C) views of UMAG 53643, left I2 of Pararctotherium sp. Labial (D) and occlusal (E) views of MLP 00-VII-15-1, right I2 of Arctotherium latidens. Labial (F) and occlusal (G) views of MACN 971, right I2 of the holotype of Pararctotherium pamparum.

gonia. This is one of the youngest records of the genus, and the southernmost record of Ursidae in the world.

\section{PALEOENVIRONMENT AND PALEOECOLOGY}

The colonization of southwestern Patagonia by Pararctotherium must have occurred after the last Glacial Maximum (20,000-18,000 yBP), because glacial ice covered this part of Patagonia (Clapperton et al., 1995; Cione and Barla, 2000). Deglaciation in southwestern Patagonia began between 16,000 and 14,000 yBP (Clapperton et al., 1995; Heusser, 1995; Rabassa et al., 2000). To the east of the Andes, xeric scrubsteppe (dominated by Empetrum) was replaced by grassland about 12,000 yBP (Markgraf, 1985, 1991, 1993). Between 12,700 and 10,300 ${ }^{14} \mathrm{C}$ yBP, ice readvanced up the Strait of Magellan, reaching as much as

TABLE 1. Measurements on the I2 of Pararctotherium sp. from Cueva de los Chingues, Chile (UMAG 53643), other Pararctotherium specimens, and Arctotherium latidens. L, greatest anteroposterior length; W, greatest transverse width.

\begin{tabular}{lcc}
\hline & $\mathrm{L}$ & $\mathrm{W}$ \\
\hline Pararctotherium sp. (UMAG 53643) & 11.3 & 8.25 \\
P. pamparum (MACN 971) & 14.1 & 9.2 \\
Pararctotherium sp. (MMP 1233M) & 11.7 & 8.2 \\
A. latidens (MACN 12529) & 17.6 & 11.1 \\
A. latidens (MMP48S) & 15.8 & 10.9 \\
A. latidens (MLP 97-I-5-1) & 15.5 & 10.5 \\
A. latidens (MLP 82-X-22-1) & 15.4 & 10.8 \\
A. latidens (MLP 00-VII-15-1) & 17.4 & 11.9 \\
A. latidens (MMP1232M) & 16.9 & 12.5 \\
\hline
\end{tabular}


$80 \mathrm{~km}$ beyond its current margins (McCulloch et al., 2000). Between 12,300 and $10,300{ }^{14} \mathrm{C}$ yBP, frequent changes of short duration (ca. 100$200 \mathrm{yr}$ ) between grassland and heathland occurred, but they do not provide an unambiguous signal of climatic cooling, and the pollen evidence of increased heathland vegetation reflects an increase in effective moisture when compared with the previous 2,000 years (McCulloch et al., 2000).

The latest Pleistocene mammalian fauna of southern Patagonia (Borrero, 1997) included grazers such as equids (Hippidion), camelids (Lama gracilis), and mylodont ground sloth (Mylodon), a mixed-feeding camelid (Lama guanicoe), and carnivores (Panthera onca mesembryna, Puma concolor, Smilodon sp., Dusicyon avus) (Markgraf, 1985; Alberdi et al., 1987; Menegaz et al., 1989; Canto, 1991; Borrero, 1997), but was less diverse than that of lower latitudes (e.g., Pampean region). The first record of humans in southern Patagonia is accurately dated around 11,000 yBP (Borrero, 1999). The Paractotherium I2 at the Cueva de los Chingues was found together with fossils of Hippidion, Mylodon, Lama guanicoe, large felids (Puma concolor and possibly Panthera onca mesembryna), canids, and rodents (San Roman et al., 2000).

The record of Pararctotherium at Cueva de los Chingues is synchronic with the cold grassland event (see above), thus some species of Pararctotherium were adapted to live in open, arid, and/or cold environments. This agrees with previous hypotheses on Pararctotherium paleoecology (Berman, 1994; Trajano and Ferrarezzi, 1994; Cartelle, 1998; Soibelzon and Bond, 1998).

Acknowledgments - We thank the following persons and institutions for allowing as to examine ursid material: José Bonaparte and Alejandro Kramartz, Museo Argentino de Ciencias Naturales "Bernardino Rivadavia"; Alejandro Dondas, Museo Municipal de Ciencias Naturales de Mar del Plata "Lorenzo Scaglia"; Marcelo Reguero, Museo de La Plata. Eduardo Tonni, Cecilia Deschamps, Ulyses F. J. Pardiñas, and Luis Borrero provided valuable suggestions on the manuscript.

\section{LITERATURE CITED}

Alberdi, M. T., A. N. Menegaz, and J. L. Prado. 1987. Formas terminales de Hippidion (Mammalia, Perissodactyla) de los yacimientos del Pleistoceno tardío-Holoceno de la Patagonia (Argentina y Chile). Estudios Geológicos 43:107-115.

Ameghino, F. 1904. Nuevas especies de mamíferos cretáceos y terciários de la República Argentina. Anales de la Sociedad Científica Argentina 56:193-208.

Berman, W. D. 1994. Los carnívoros continentales (Mammalia, Carnivora) del Cenozoico en la provincia de Buenos Aires. Ph.D. dissertation, Universidad Nacional de La Plata, La Plata, Argentina, 413 pp.

Borrero, L. A. 1997. The extinction of the megafauna: a supra-regional approach. Anthropozoologica 25/26:209-216.

1999. Human dispersal and climatic conditions during Late Pleistocene times in Fuego-Patagonia. Quaternary International 53/ 54:93-99.

Canto, J. 1991. Posible presencia de una variedad de Smilodon en el Pleistoceno tardío de Magallanes. Anales del Instituto de la Patagonia, ser. Ciencias Humanas 20:96-99.

Cartelle, C. 1994. Tempo Passado. Mamíferos do Pleistoceno em Minas Gerais. Ediciones Palco, Brazil, 131 pp.

- 1998. Um pequeno urso do Pleistoceno final da Bahia. Acta Geologica Leopoldensia 46/47:171-189.

Cione, A. L., and E. P. Tonni. 1999. Biostratigraphy and chronological scale of uppermost Cenozoic in the Pampean Area, Argentina; pp. 23-51 in E. P. Tonni and A. L. Cione (eds.), Quaternary Vertebrate Paleontology in South America. Quaternary of South America and Antarctic Peninsula 12

, and M. J. Barla. 2000. First fish record in the Lago Belgrano of Argentina and origin of fish populations in Patagonian lakes. Biogeographica 76:41-48.

Clapperton, C. M., D. E. Sugden, D. S Kaufman, and R. D. McCulloch 1995. The last glaciation in central Magellan Strait, southernmost Chile. Quaternary Research 44:133-148.

Emslie, S. 1995. The fossil record of Arctodus pristinus (Ursidae: Tremarctinae) in Florida. Bulletin of the Florida Museum of Natural History 37:501-514.

Heusser, C. 1995. Three late Quaternary pollen diagrams from southern Patagonia and their palaeoecological implications. Palaeogeography, Palaeoclimatology and Palaeoecology 118:1-24.

Hunt, R. M. 1996. Biogeography of the order Carnivora; pp. 485-541 in J. L. Gittleman (ed.), Carnivore Behavior, Ecology, and Evolution. Cornell University Press, Ithaca and London.

Kraglievich, L. 1926. Los Arctoterios norteamericanos (Tremarctotherium, n. gen.) en relación con los de Sud América. Anales del Museo Nacional de Historia Natural "Bernardino Rivadavia" 34(56):1-16.

1934. La antigüedad Pliocena de las faunas de Monte Hermoso y Chapadmalal, deducidas de su comparación con las que le precedieron y sucedieron. El Siglo Ilustrado, Montevideo, $136 \mathrm{pp}$.

-, and C. Ameghino. 1940. Los úrsidos extinguidos de Sud América; pp. 557-627 in A. J. Torcelli and C. A. Marelli (eds.), Obras de Paleontología y Geología, 3 vols. Ministerio de Obras Públicas de la Provincia de Buenos Aires, La Plata.

Kurtén, B. 1966. Pleistocene bears of North America: 1. Genus Tremarctos, spectacled bears. Acta Zoologica Fennica 115:1-120.

1967. Pleistocene bears of North America: 2. Genus Arctodus, short faced bears. Acta Zoologica Fennica 117:1-60.

McCulloch, R. D., M. J. Bentley, R. S. Purves, N. R. Hulton, D. E. Sugden, and C. M. Clapperton. 2000. Climatic inferences from glacial and palaeoecological evidence at the last glacial termination, southern South America. Journal of Quaternary Science 15:409_ 417.

Markgraf, V. 1985. Late Pleistocene faunal extinction in southern Patagonia. Science 228:1110-1112.

1991. Late Pleistocene environmental and climatic evolution in southern South America. Bamberger Geographische Schritten 11: 271-281.

1993. Paleoenviroments and paleoclimates in Tierra del Fuego and southernmost Patagonia, South America. Palaeogeography, Palaeoclimatology and Palaeoecology 102:53-68.

Menegaz, A. N., F. J. Goin, and E. Ortiz Jaureguizar. 1989. Análisis morfológico y multivariado de los representantes fósiles y vivientes del género Lama (Artiodactyla, Camelidae). Sus implicancias sistemáticas, biogeográficas, ecológicas y biocronológicas. Ameghiniana 26:153-172.

Merriam, J., and C. Stock. 1932. The Felidae of Rancho La Brea. Publication of the Carnegie Institution of Washington 422:1-231.

Oliver, C. 1935. Mamíferos fósiles de Chile. Adiciones y correcciones a una lista preliminar. Revista Chilena de Historia Natural 30:144156.

Pardiñas, U. F. J., E. P. Tonni, and A. Figini. 1998. Camet Norte: diversidad faunística próxima al Ultimo Máximo Glacial en el sudeste de la provincia de Buenos Aires (Argentina). Proceedings of $\mathrm{X}$ Congreso Latinoamericano de Geología y VI Congreso Nacional de Geología Económica 1:257-262.

Paula Couto, C. 1960. Um urso extinto do Brasil. Boletim da Sociedade Brasileira de Geologia 9:5-27.

Perea, D., and M. Ubilla. 1983. Arctodus pamparus (Ameghino) (Mammalia, Ursidae) en sedimentos Lujanenses del dep. Río Negro, Uruguay. Resúmenes y Comunicaciones de las Jornadas de Ciencias Naturales 3:88-91.

Rabassa, J., A. Coronato, G. Bujalesky, M. Salemme, C. Roig, A. Meglioli, C. Heusser, S. Gordillo, F. Roig, A. Borromei, and M. Quattrocchio. 2000. Quaternary of Tierra del Fuego, southernmost South America: an update review. Quaternary International 68-71: 217-240.

San Roman, M. B., F. R. Morello, and A. I. Prieto. 2000. Cueva de los Chingues (Parque Nacional Pali Aike), Magallanes, Chile. Historia natural y cultural I. Anales del Instituto de la Patagonia Serie Ciencias Historicas 28:125-146.

Smith Woodward, E. 1900. On some remains of Gryphotherium (Neomylodon) listai and associated mammals from a cavern near Consuelo Cave, Last Hope Inlet, Patagonia. Proceedings of the Zoological Society of London 1:64-79.

Soibelzon, L. H. 2000. Nueva evidencia sobre la relación filogenética entre los osos Pleistocenos de America del Sur y del Norte. Asociación Geológica Argentina, Serie D, Publicación Especial 4:4550

2002. Los Ursidae (Carnivora, Fissipedia) fósiles de la República Argentina. Aspectos Sistemáticos y Paleoecológicos. Ph.D. dissertation, Universidad Nacional de La Plata, La Plata, Argentina, $238 \mathrm{pp}$.

, and M. Bond. 1998. Los Ursidae (Mammalia: Carnivora) Fósiles de la República Argentina. Proceedings of X Congreso Lati- 
noamericano de Geologia y VI Congreso Nacional de Geologia Económica I:275-279.

and E. Soibelzon. 2000. The systematic identity of the type of Arctotherium bonariensis Gervais, 1852 (Ursidae: Tremarctinae). Ameghiniana 37(4)-Suplemento.

, E. P. Tonni, and M. Bond. 2001. Arctotherium latidens (Ursidae, Tremarctinae) en el Pleistoceno de la Provincia de Buenos Aires, Argentina. Comentarios Sistemáticos y Bioestratigráficos. Proceedings of XII Congreso Latinoamericano de Geología y III Congreso Uruguayo de Geología, 6 pp. (Electronic version without pagination.)

Tedford, R. H., and J. Martin. 2001. Plionarctos, a tremarctine bear
(Ursidae: Carnivora) from western North America. Journal of Vertebrate Paleontology 21:311-321.

Trajano, E., and H. Ferrarezzi. 1994. A fossil bear from northeastern Brazil, with a phylogenetic analysis of the South American extinct Tremarctinae (Ursidae). Journal of Vertebrate Paleontology 14: $552-561$.

Ubilla, M., and D. Perea. 1999. Quaternary vertebrates of Uruguay: a biostratigraphic, biogeographic and climatic overview; pp. 75-90 in E. P. Tonni and A. L. Cione (eds.), Quaternary Vertebrate Paleontology in South America. Quaternary of South America and Antarctic Peninsula 12.

Received 6 August 2001; accepted 18 June 2002. 